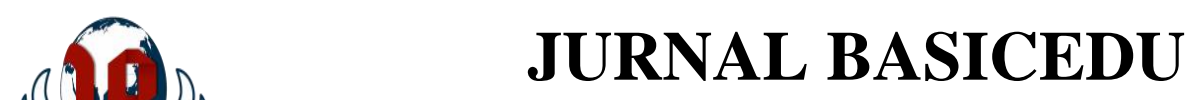

Volume 5 Nomor 2 Tahun 2021 Halaman 835 - 841

Research \& Learning in Elementary Education https://jbasic.org/index.php/basicedu

\title{
Pengembangan Modul Pembelajaran IPA Berbasis Picture And Picture di Sekolah Dasar
}

\author{
Risda Amini ${ }^{1 凶}$, Saniyah Oktarisma ${ }^{2}$ \\ Pendidikan Guru Sekolah Dasar, Universitas Negeri Padang, Indonesia ${ }^{1,2}$ \\ E-mail: Saniyahoktarisma50@ gmail.com¹, Risdamini@yahoo.co.id ${ }^{2}$
}

\begin{abstract}
Abstrak
Penelitian ini bertujuan untuk mengembangkan modul pembelajaran IPA berbasis picture and picture untuk kelas V di SDN 197/II Pulau pekan. Jenis penelitian yang digunakan adalah pengembangan (Research and Development) dengan menggunakan modifikasi model 3-D yaitu terdiri dari tahap define, tahap design, dan development. Penelitian ini dilakukan pada semester ganjil tahun ajaran 2021/2022. Validator angket terdiri dari 1 orang dosen validator design dan 1 orang dosen sebagai validator materi. Berdasarkan hasil penelitian, validasi modul yang dihasilkan dari aspek tampilan modul IPA berbasis picture and picture memperoleh nilai 3,60 dan dari aspek materi memperoleh penilaian 3,90 dan dilihat rata-rata skor penilaian modul pembelajaran IPA berbasis picture and picture yang diperoleh secara keseluruhan yaitu 3,70 dengan kategori sangaat valid. Sedangkan uji praktikalitas terdiri dari 1 orang guru dan 22 orang siswa. Dari hasil praktikalitas oleh guru dengan persentase hasil 96\% dan dari hasil praktikalitas oleh siswa diperoleh persentase hasil 95\%. Dari hasil penelitian ini dapat disimpulkan bahwa modul pembelajarnan IPA berbasis picture and picture yang dihasilkan sangat valid dan praktis digunakan dalam pembelajaran IPA. Sehingga dapat digunakan dalam pembelajaran IPA di kelas V SD.

Kata kunci : Pengembangan Modul, Picture and picture, IPA.
\end{abstract}

\begin{abstract}
This study aims to develop a picture and picture-based science learning module for grade V at SDN 197 / II Pulau Pekan. The type of research used is the development (Research and Development) by using a 3-D model modification, which consists of the define stage, the design stage, and development. This research was conducted in the odd semester of the 2021/2022 school year. The questionnaire validator consisted of 1 design validator lecturer and 1 lecturer as material validator. Based on the results of the study, the module validation resulted from the display aspect of the picture and picture-based science module obtained a value of 3.60 and from the material aspect obtained an assessment of 3.90, and seen the average score of the picture and picture-based science learning module assessment obtained as a whole. that is 3.70 with very valid category. While the practicality test consisted of 1 teacher and 22 students. From the results of practicality by the teacher with a percentage of $96 \%$ and from the results of practicality by students obtained a percentage of 95\%. From the results of this study it can be concluded that the resulting picture and picture-based science learning module is very valid and practical to use in science learning. So that it can be used in science learning in grade $V S D$.
\end{abstract}

Key words: Module Development, Picture and picture, Science.

Copyright (c) 2021 Risma Amini, Saniyah Oktarisma

Corresponding author :

Email : Risdamini@yahoo.co.id

DOI : https://doi.org/10.31004/basicedu.v5i2.769 
DOI : https://doi.org/10.31004/basicedu.v5i2.769

\section{PENDAHULUAN}

Pendidikan memiliki peran yang sangat penting dalam kehidupan manusia, karena dapat mempengaruhi perkembangan semua aspek kepribadian dalam kehidupannya. Pendidikan adalah kegiatan universal dalam kehidupan manusia, karena dimanapun dan kapan pun di dunia adaa pendidikan. Pendidikan pada dasarnya adalah upaya manusia untuk memanusiakan manusia itu sendiri (Zairmi, Yanti, Risda 2019).

Ilmu Pengetahuan Alam (IPA) merupaakan bagian dari kehiidupan, secara singkat IPA dapat diartikan pengetahuan yang rasional tentang alam semestaa dengan segala isinya. Hal ini sejalann dengan pendapat Samatowa (2016:3) menyatakan bahwa IPA atau science dapat disebuut sebagai ilmu pengetahuan alamm, atauu ilmu yang memeplajari perstiwa-peristiwaa yang terjadi di alam. Berdasarkann hal tersebut Pembelajarann IPA hendaknyaa membukaa kesempatan untuk siswa membanguun pengetahuann sendirii dengan aktif melalui pengamatan maupun percobaan-percobaan dalam proses pembelajarann.

Ruang lingkup Ilmuu Pengetahuann Alam (IPA) yang diajarkan pada jenjang SD meliputi 1) makhluk hiidup dan proses kehidupan 2) bendaa/materi, sifat-sifat dan kegunaannya 3) enerrgi dan perubahannya 4) buumi dan alam (BNSP 2006:162)

Dalam proses pembelajaran, guru perlu memilikii keterampilann untuk mengembanggkan mediaa pembellajaran. Depdiknass (2008:12) mengungkapkan bahwa media pembelajaran yang dapat digunakan dan dikembangkan guru adalahh bahan ajarr cetak (printed) seperti handout, buku, modul, lembar kerja siswa, brosur, leaflet, wallchart, foto/gambar, dengan pendekatan/maket. Namun bahan ajar yang lebih efektiif dan efisien adalaah modull karenaa modul disusun sistematis yang memungkinkann siswa belajar mandirii.

Berdasarkann hasil observasi dan wawancara yang penulis lakukan dengan guruu kelas V SDN 197/II Pulau Pekan, guru menggunakan metode ceramah dan tanya jawab selama proses pembelajaran berlangsung. Guru menerangkann materi masih menggunakan buku paket yang merekaa dapat dari perpustakaaan dan LKS yanng di datangkan dari luar sekolahh, dimana buku paket dan LKS yang tersedia membuatt tidak semnagatnya siswa belajarr dan bukuu tersebut tampilannya kurang menarikk perhatiann. Untuk mengatasi perrmasalahan tersebut, maka dapat dikembangkan bahan ajar berupa modul berbasis picture and picture. Natalina (2012:2) picture and picture ini berbeda dengan media gambar dimana picture and picture berupa gambar yang belum disuusun secara berurutan dan yangg menggunakannya adalahh siswa, sedangkan media gambar berupaa gambar utuh yang digunakan oleh guruu dalam proses pembelajaran. Dengann adanya penyusunan gambarr guruu dapat mengetahuii kemampuan siswa dallam memahami konsep materii dan melatihh berpikir logis dan sistematiss, dapat melihat kemampuann siswa dalam menyusun gambar secara beruruutan, mennjukkan gambar, memberi keterangann dan menjelaskann gambar. Adanyaa gambar-gambar yang berkaitan dengan materii belajarr siswa lebih aktiif dan dapaat tercapaii tujuan akhiir dari proses pembelajaraan yaituu haasil belajar akan meningkatt.

Berdasarkann lattar belakang yang tellah dikemukakan dapat diidentifikasiikan masalahh sebagai berikut: Tidak adanya modul, menyebbkan siswa menjadii dominan mendengarkan dan mencatat materi saja yng sekaligus menjadi salaah satuu faktorr pembelajarann yang tidak aktf melibatkan siswa dalam beljar.Buku paket yang digunakan kurang menarikk karena tidak memilikii gambar yang jelass dan warnaa yang bervariiasi.Kemampuann guru masih kurang dalam menyiappkan mediaa pembelajaran.Selain itu maka penelitiann ini adalahh :Menghasilkan Modul Ilmuu Pengetahuann Alam (IPA) berbasis picture and picture untuk siswa kelas V SDN 197/II Pulau Pekan memenuhii kriteria valid dan kriteriia praktis. 


\section{METODE PENELITIAN}

Model pengembangann ini adalaah model pengembangan 4-D yang terdiri dari tahap pendefenisian (define), perancangaan (designe), pengembangan (develoep) dan penyarab (disseminate) yang telah dimodifikasi menjadi 3-D yang terdiri dari tiga tahap dan melalui revisi oleh dosen ahli. Menurut Sari (2017:23-24) tahap-tahap itu adalah pendefenisian (defin), perancangan (designe), pengembangan (develop). Selanjutnya produk divalidasi oleh ahli, kemudian diuji cobakan pada peserta didik kelas V SDN 197/II Pulau Pekan.

\section{a. Tahap Pendefenisian (Define)}

Pada tahap definee dilakukan penetapan syrat-syarat pembelajaran dengan menganalisis standart kompetensi dan materi pembelajaran berdasarkan standar isi kurikulum 2013. Tujuan analisis ini adalah untuk mendefenisikan secara jelas perincian program atau rancangan. Pada tahap ini peneliti menganalisis hal yang terkait dengan pengembangan modul antara lain: (a) analisis kurikulum; (b) analisis kebutuhan; (c) analisis siswa; dan (d) analisis konsep.

\section{b. Tahap Perancangan (Design)}

Selanjutnyaa dirancang modul IPA dengan berbasis modul picture and picture untuk peserta didik yang disesuaikan dengan indikator dan tujuan pembelajaran yang telah ditentukan dalam perancangan modul pembelajaran. Kegiatan yng dilakukan adalah :1.Menyiapkan buku referensi yang berkaitan dengan materi yang akan dikembangkan menjadi sebuah modul dengan berbasis model picture and picture. 2.Mendesain modul, meliputi kata pengantarr, daftar isi, petunjuk modul, kerangkaa modul pembelajaran, standarr kompetensi, kompetensi dasar, indikator, tujuan pembelajaran, peta konsep, materi, rangkuman, latihan dan daftar pustaka.3.Menyusun desain instrumen penilaian, instrumen penilaian modul dikembangkan untuk menilai kevalidan dan kepraktisan modul. Kevalidan modul akan dinilai oleh ahli pendidikan yang sesuai dengan bidang kajiannya, yaitu ahli materi dan ahli desain pembelajaran. Sedangkan instrumen penilaian ketepatan desain pembelajaran, ketepatan isi bahan ajar dan kemenarikan modul berupa angket respon pendidik dan peserta didik.

\section{c. Tahap Pengembangan (Develope)}

Tujuan dari tahap ini adalah untuk menghasilkan modul dengan berbasis model picture and picture yang valid dan praktis. Modul yang dikembangkan akan direvisi berdasarkan masukan dari validator. Tahap pengembangan meliputi :Tahapan yang dilakukn yaitu tahap validasi dan praktikalitas. Untuk tahap validasi dilakukan oleh para pakar, tahap praktikalitas dilakukan oleh guru dan siswa kelas V SDN 197/II Pulau Pekan.

\section{Analisis Data Hasil Validasi Modul Pembelajaran}

Data hasil validasi modul pembelajarann yang diperoleh, di analis terhadap seluruh aspek yang disajikan dalam bentuuk tabel dengan menggunakan Skala Liker, selanjutnya dicari rata nilai dengan menggunakan rumus berikut ( Sari 2017:24).

$$
R=\frac{\mathrm{Vij}}{\mathrm{nm}}
$$


DOI : https://doi.org/10.31004/basicedu.v5i2.769

Tabel 1. Penilaian Validitas

\begin{tabular}{|c|c|}
\hline Rentang & Kategori \\
\hline $1,00-1,99$ & Tidak Valid \\
\hline $2,00-2,99$ & Kurang Valid \\
\hline $3,00-3,49$ & Valid \\
\hline $3,50-4,00$ & Sangat Valid \\
\hline
\end{tabular}

\section{Analisis Hasil Praktikalitas Modul}

Data uji praktikalitas modul pembelajaran IPA berbasis model picture and picture dianalisis dengan rumus sebagai berikut (Yanti, 2014:130).

$$
\text { Nilai praktikalitas }=\frac{\text { jumlah skor yang diperoleh }}{\text { skor maksimum }} \times 100 \%
$$

Tabel 2. Presntase Penilaian Praktikalitas

\begin{tabular}{|c|c|}
\hline Presentase & Kriteria \\
\hline $0-54 \%$ & Tidak praktis \\
\hline $55-59 \%$ & Kurang Praktis \\
\hline $60-75 \%$ & Cukup praktis \\
\hline $76-85 \%$ & Praktis \\
\hline $86-100 \%$ & Sangat praktis \\
\hline
\end{tabular}

\section{HASIL DAN PEMBAHASAN}

Secara umum, hasil validasii Modul berbasis picture and picturee dapat di gambarkan pada tabel 3 sebagai berikut:

Tabel 3. Hasil Validasi Modul Berbasis Picture and Picture oleh Validator

\begin{tabular}{|c|c|c|c|c|c|c|}
\hline \multirow[t]{2}{*}{ No } & \multicolumn{2}{|c|}{ Aspek Yang Dinilai } & \multirow{2}{*}{$\begin{array}{c}\text { Penilaian } \\
\text { Validator } \\
\text { V1 }\end{array}$} & \multirow{2}{*}{$\begin{array}{c}\text { Skor } \\
\text { V2 }\end{array}$} & \multicolumn{2}{|c|}{ Kategori } \\
\hline & V1 & $\mathrm{V} 2$ & & & & \\
\hline 1 & Didaktik & Tampilan & 3,81 & 3,33 & 3,52 & \begin{tabular}{|l|} 
Sangat Valid \\
\end{tabular} \\
\hline 2 & Konstruksi & Komponen & 3,91 & 3,50 & 3,66 & Sangat Valid \\
\hline 3 & Teknis & & 3,85 & & 3,80 & Sangat Valid \\
\hline \multicolumn{3}{|c|}{ Rata-rata } & 3,90 & 3,60 & 3,70 & \begin{tabular}{|l} 
Sangat Valid \\
\end{tabular} \\
\hline
\end{tabular}

Berdasarkan Tabel 3 dapat dilihat persentase validasi modul yang dinilai dari dua validator secara umum adalah 3,60 dan 3,90 dengan kategori Sangat Valid dan Valid. Dari dua aspek yang dinilai di dapat rata-rata didaktik adalah 3,81, aspek konstruksi 3,91 dan teknis 3,85. Dari tabel 5 didapatkan rata- rata validitas dari kedua validatorr adalah 3,90 sudah menunjukan bahwa modul IPA berbasis picture and picture yang dikembngkan sudah valid.

Kemudian peneliti memperoleh skor dari prakalitas modul seorang guru yaitu $96 \%$ dengan kriteria sangat praktis. Secara rinci dapat dilihat pada tabel berikut. 
Amini , Saniyah Oktarisma

DOI : https://doi.org/10.31004/basicedu.v5i2.769

Tabel 4. Rekapitulasi Hasil Lembar Praktikalitas oleh Guru

\begin{tabular}{|l|l|l|c|l|}
\hline No & Aspek Penilaian & $\begin{array}{c}\text { Total } \\
\text { Skor }\end{array}$ & $\begin{array}{c}\text { Persentase } \\
\text { Praktikalitas }\end{array}$ & \multicolumn{1}{|c|}{ Kriteria } \\
\hline 1 & Kemudahan Penggunaan & 19 & $97 \%$ & Sangat Praktis \\
\hline 2 & Efektivitas Waktu Pembelajaran & 7 & $92 \%$ & Praktis \\
\hline 3 & Manfaat & 23 & $97 \%$ & Sangat Praktis \\
\hline & Rata-rata & & $\mathbf{9 6 \%}$ & Sangat Praktis \\
\hline
\end{tabular}

Selain dari guru peneliti juga memperoleh data praktikalitas modul dari dua puluh dua siswa, dengan rata-rata kepraktisan modul 95\% dan kategori sangat praktis. Berikut tabel hasil analisis praktikalitas modul oleh siswa.

Tabel 5. Rekapitulasi Hasil Lembar Praktikalitas oleh Siswa

\begin{tabular}{|c|c|c|c|c|}
\hline No & Aspek Penilaian & $\begin{array}{l}\text { Total } \\
\text { Skor }\end{array}$ & $\begin{array}{c}\text { Persentase } \\
\text { Praktikalitas }\end{array}$ & Kriteria \\
\hline 1 & Minat Siswa & 487 & $94 \%$ & Sangat Praktis \\
\hline 2 & Proses Penggunaan & 240 & $93 \%$ & Praktis \\
\hline 3 & $\begin{array}{l}\text { Peningkatan Keaktifan } \\
\text { siswa }\end{array}$ & 249 & $94 \%$ & Sangat Praktis \\
\hline 4 & Waktu Yang Tersedia & 125 & $94 \%$ & Sangat Praktis \\
\hline 5 & Evaluasi & 120 & $91 \%$ & Praktis \\
\hline \multicolumn{3}{|c|}{ Rata - rata } & $95 \%$ & Sangat Praktis \\
\hline
\end{tabular}

\section{Validitas Modul Pembelajaran}

Hasil validitas modul yang dinilai oleh validator diketahui rata-rata secara umum adalah 3,76 dengan kategori sangat valid. Dari aspek-aspek yang dinilai didapat skor pada aspek didaktik yaitu 3,8 dengan kategori sangat valid. Indikator penilaian aspek didaktik yaitu modul yang dikembangkan sesuai dengan kurikulum 2013, kelengkapan dan kejelasan materi, membantu peserta didik mengkonstruksikan pengetahuan dan membantu peserta didik menemukan konsep. Untuk aspek konstruksi yaitu 3,8 dengan kategori sangat valid, dimana indikator penilaiannya adalah susunan kalimat yang mudah dipahami, terdapat informasii tambahann, dan sesuai dengan Ejaan Bahasa Indonesia (EBI).Hal ini bisa dilihat pada perolehan nilai rata-rata aspek teknis yaitu 3,8 dengan kategori sangat praktis. Hal ini memandakan modul yang dikembangkan memiliki kejelassan petunjuk, modul dijabarrkan dapat menuntun peserta didik menemukan konsep sesuai dengan tujuan pembelajaran dan dapat memfasilitasi peserta didik belajar mandiri sertaa evaluasi dalam modul pembelajaran yang telah dikembangkan dapat mengukur ketercapaian kompetensi. Berdasarkan validasi dari validator modul pembelajaran IPA berbasis picture and picture yang dikembangkan berada pada kategori sangat valid. Hal ini diperoleh dari hasil validator yaitu 3,76. Dan dapat dikatakan kesahan isi modul dapat diipertanggung jawabkan karna telah divalidasi oleh dosen ahli.

\section{Hasil Praktikalitas Modul}

Modul pembelajarn IPA brbasis picture and picturee yang telaah dinyatakan valid dan validator selanjutnya diuuji cobakan di V SDN 197/II Pulau Pekan untuk menilai tingkat praktikalitas modul pembelajaran IPA berbasis picture and picture. Hasil uji praktikalitas modul pembelajaraan IPA berbasis picture and picture dapat dijelaskan sebagai berikut : 
DOI : https://doi.org/10.31004/basicedu.v5i2.769

a. Praktikalitas modul pembelajaran oleh pendidik

Analisis hasil uji praktikalitas oleh pendidik kelas V SDN 197/II Pulau Pekan menunjukann modul pembelajaran IPA berbasis picture and picture dengan persentase kepraktisan $96 \%$. Hal ini menunjukan bahwsanya modul pembelajaran yang dikembangkan dapat mempermudah pendidik dalam menjelaskan materi IPA serta membantu peran pendidik sebagai fasilitator.

b. Praktikalitas modul pembelajaran oleh peserta didik

Analisis data hasil uji praktikalitas oleh peserta didik kelass V SDN 197/II Pulau Pekan menunjukan bahwa modul IPA berbasis picture and picture yang telah dikembangkan sangat praktis dengan persentase kepraktisan 95\%. Persentase tersebut mennjukan bahwa modul ini sangat praktis dari aspek minat siswa, aspek proses penggunaan, aspek peningkatan kreatifitas siswa, aspek waktuu yang tersedia, dan aspek evaluasi.

3. Kendala dan keterbatasan penelitian

Kendala-kendala yang ditemukan dalam pengembangan modul pembelajaran IPA berbasis picture and picture ini adalah peneliti menyadari bahwasanya dalam penelitian ini pasti terjadi banyak kendala dan hambatan. Hal ini bukan karena faktor kesengajaan, akan tetapi karena keterbatasan dalam melakukan penelitian hal itu karena keterbatasan-keterbatasn di bawah ini :
a. Keterbatasan Lokasi
b. Keterbatasan Materi dan Tempat Penelitian
c. Keterbatasan kemampuan
d. Keterbatasan Waktu
e. Modul mash dicetak dengan mesin cetak biasa sehingga masih adaa kualitas gambar dan warna yang masih kurang maksimal.

\section{KESIMPULAN}

1. Validitas modul pembelajaran IPA berbasis picture and picture untuk kelas V SDN 197/II Pulau Pekan yang telaah dikembangkan dengan validitas oleh ahli materi yaitu 3,86 dan validitas oleh ahli desain yaitu 3,51 maka rata-rata dari kedua validator adalah 3,68 sudah menunjukan bahwa modul IPA berbasis picture and picture yang dikembangkan sudah valid.

2. Praktikalitas modul pembelajaran IPA berbasis picture and picture untuk kelas V SDN 197/II Pulau Pekan yang telah dikembangkan dinyatakan sangat praktis dengan rata-rata persentase kepraktisan $96 \%$ oleh pendidik dan dinyatakann sangat praktis dengan rata-rata persentase kepraktisan 95\% oleh peserta didik.

\section{DAFTAR PUSTAKA}

Baransano, A. Y., Yohanita, A. M., \& Damopolii, I. (2017). Penerapan Model Pembelajaran Picture and Picture untuk Meningkatkann Hasil Belajar Biologi Siswa Kelas XI IPA SMA YABT Manokwari. In Prosiding Seminar Nasional MIPA II Tahun 2017 (pp. 273-280)

Daryantoo. (2013). Menyusun Modul Bahan Ajar Untuk Persiapan Guru Dalam Mengajar. Yogyakarta: Gava Mediaa.

Istaranii. (2012). 58 Model Pembelajaran Inovatif. Medan: Media Perkasaa.

Natalinaa, M., Yusuf, Y., \& Rahmayani, D. (2012). Penerapan Model Pembelajarann Kooperatif Picture And Picture untuk Meningkatkan Aktivitas dan Hasil Belajar Biologi Siswa Kelas XI IPA SMA N 1 Ukuii 
841 Pengembangan Modul Pembelajaran IPA Berbasis Picture And Picture di Sekolah Dasar - Risma Amini , Saniyah Oktarisma

DOI : https://doi.org/10.31004/basicedu.v5i2.769

Tahun Ajaran 2009/2010. BIOGENESSIS (JURNAL PENDIDIKAN SAINS DAN BIOLOGI), 7(02). Hal 2

Sarii, R. T. (2017). Uji Validitass Modul Pembelajaran Biologi Pada Materi Sistem Reproduksi Manusiaa Melalui Pendekatan Konstruktivisme Untuk Kelas IX SMP. Scientiae Educatia, 6(1), 22-26.

Sarii, R. T., \& Jusarr, I. R. (2017). Analisis Kebutuhan Modul Pembelajaran IPA Berorientasi Pendidikan Karakter melalui Pendekatan Quantum Learninng di Sekolah Dasar. BIOEDUUKASI (Jurnal Pendidikan Biologi), 8(1), 26-32.

Zairmi, Ulil, Yanti Fitria, and Risda Amini. "Penggunaan Model Pembelajaran Two Stay Two Stray Dalam Pembelajaran IPA DI Sekolah Dasar." Jurnal Basicedu 3.4 (2019): 1031-1037. 